\title{
PARASITOSES IN THE FRY OF SELECTED FRESHWATER FISH SPECIES UNDER THE CONDITIONS OF STRIPPING AND REARING
}

\author{
S. NAVRÁTIL \\ Department of Poultry, Fish, Bee and Game Diseases University of Veterinary Science, \\ 61242 Brno
}

Received April, 25, 1990

\begin{abstract}
Navrátil S.: Parasitoses in the Fry of Selected Freshwater Fish Species under the Conditions of Stripping and Rearing. Acta vet. Brno, 60, 1991: 357-366.

During the period from 1984 to 1989 the problem of parasitic invasion into the artificially reproduced and reared fry of the freshwater fish species (Barbus barbus, Chondrostoma nasus, Leuciscus cephalus, Aspius aspius) were investigated at a specialized fish breeding farm of the Czech Angler's Union in Třebíz-Poušov situated on the river Jihlava (the Danube river basin). The invasion with parasites was investigated in 979 fish specimens ( 846 juvenile, 133 adult) of the selected species and in 257 fish of other species.

The reared fry of the selected fish species were found to be endangered already in their first days of life, predominantly by ectoparasitic protozoa with not definitely formed host specificity.

Thus optimal rearing conditions have to be assured, along with regular examination of the health status. Efficient preventive antiparasitic baths have to be applied. It is advantagenous to complement these measures with an effective way of sanitation of the fish-rearing farms, by the investigation of the health status of fish in the feeder of the fish-hatchery and rearing pond with its regulated stocking, or possibly by declaring relevant areas as being protected with the introduction of a closed turnover of the parent fish shoal.
\end{abstract}

Barbus barbus, Chondrostoma nasus, Leuciscus cephalus, Aspius aspius, ectoparasitic protozoa, zooveterinary measures

The industrial development, intensification in agriculture and the growth of residential areas are the principal sources of water pollution. The living conditions in water courses have changed in recent years due to waste water discharge, run-offs from surface drainage, the increase of eutrophisation, acid rain, and water course regulation. This caused that some of the fish species have lost their viability in these waters, and in other the fish-planting cannot be ensured by a natural reproduction. It has thus been necessary to proceed to artificial stripping, rearing and planting of these fish species. This concerns also the investigated fish species (barbel - Barbus barbus, nase - Chondrostoma nasus, chub - Leuciscus cephalus and asp - Aspius aspius). The introduction of the above mentioned modern technologies of reproduction and rearing results in new problems concerning the health status of fish.

Technological processes of stripping and rearing of fry for the fish species mentioned above have been worked out only recently but in some cases they are still missing. During our investigation only the methods of stripping and rearing for the barbel species were available in a complete form applicable for our fishery (Krupka 1987). Pecha (1986) reported on his experience with stripping and rearing of the asp. The method of artificial stripping and rearing of the investigated species is thus based on the procedures worked out for other fish species and on the experience of hatcherymen and breeders.

The success of stripping and rearing, with the smallest possible health problems and losses 
of the reared fry, is dependent upon many circumstances participating more or less in the development of good health condition of the fry. These circumstances have been presented to various extent in almost all surveys concerned with fish diseases (e.g. Bauer et al. 1983; Dyk 1961; Lucký 1986a, b; Schäperclaus et al. 1979).

The spawn incubation should not be affected by unexpected events provided that established technological procedures are observed when manipulating with the spawn. A certain danger is seen in saprolegniosis of the spawn that can, however, be suppressed by the use of suitable control baths (Krupka 1987; Lucký and Navrátil 1986). The health status of the hatched fry is affected by some external factors, predominantly by the quality of water, its temperature and by the supplementary feeding (Jirásek 1980; Lucký and Navrátil 1986). Protozoan ectoparasitoses represent the highest danger occurring during the early stages of fry rearing. The seriousness of this is seen in a possibility of a rapid spread of this disease in accumulated rearing and stocking followed by a high, or even total death rate (Kouřil et al. 1984). The prevention of causal agent invasion, disinfection of rearing equipment, of implements and tools, provision of harmless water sources and supplement feed represent important control measures (Krupka 1987). Prophylaxis and therapy are carried out by various types of baths or applying a premedicated feed (Kouŕil et al. 1984; Lucký 1986a; Schäperclaus et al. 1979).

Both home and foreign literature is abundant in data concerning parasitic fauna of the investigated fish species or parasites invading them. These works concern mostly the fauna and zoology without more detailed pathogenetic and pathologic analyses (e.g. By chovskij et al. 1962; Ergens and Lom 1970; Gusev et al. 1985; Ivasik 1963; Lom, Dyková et al. 1989; Markevitch 1951; Molnár 1964, 1968, 1969, 1970; Moravec 1971; Pellérdy and Molnár 1968; Plehn 1924; Shulman et al. 1984; Vojtek 1974; Vojtek, Folkmanová and Ergens 1954; Žitňan 1960). From the presented and many other literature sources follows that apart from parasitic protozoa with not definitely formed host specificity which can parasitize on any fish host, the barbel can be invaded by more than 70 species of parasites, the nase by 60 species, the chub by almost 120 species and the asp by almost 90 species of parasites. Most of these parasitic species can be found in our country or in the river basins of our area; thus, there exists a real possibility of the fish invasion by these parasites.

The aim of the present work was to define parasitoses endangering the fry of the investigated non-traditional fish species under particular conditions in the fish-breeding farm of the Czech Angler's Union at Trrebíč - Poušov and possibly to define a character of their development and to find suitable veterinary measures to prevent the appearance of parasitoses or to find a way of combatting them.

\section{Materials and Methods}

The investigated fish-breeding farm, Fish Hatchery MO ČSR Třebíč-Poušov, belongs to the Czech Angler's Union and rears fish for its own use. The establishement was built in 1980, is situated in the valley of the Jihlava river (the Danube basin) in its barbel zone, the altitude being $425 \mathrm{~m}$. It takes up an area of 3.8 hectars. In the farm, the stripping and rearing of Barbus barbus, Chondrostoma nasus, Leuciscus cephalus, Aspius aspius, Salmo trutta, Thymallus thymallus, Stizostedion lucioperca, Lota lota and possibly of other fish species are conducted.

Fertilized and, if need be, deglutinized eggs of the investigated fish species are incubated in hatchery vessels with the bottom water feed until they hatch. The hatched fry are then reared in hatchery instruments. Later they are transferred into little ditch ponds with sufficient natural food. The stock density ranges from 200 to 500 per $\mathrm{m}^{3}$. In these ditch ponds the fry stay up to the age of 8-12 weeks, then they are caught and dispatched to individual fishery organizations. Fingerlings are then reared in smaller ponds or planted directly into free water. After transferring the fry the ditch ponds are emptied and wintered. In case of necessity the preventive long-term baths in malachite green are carried out more or less regularly (approximately once in a week) over the period of fry rearing.

The investigated fish can be divided into several groups. The first group was represented by adult fish of the examined species caught in spawning sites at various localities of the Jihlava river, or at other Southern Moravia localities. The second group included fry of these fish that were examined in more or less regular intervals from hatching to the expedition and planting into natural conditions. The fry were obtained directly at the investigated fish-breeding farm and, in very few cases, also at other farms to which they had been transferred. Since many of the invasive agents of fish diseases do not posses a specific affinity to particular fish species, and farms where stripping and rearing are carried out are often supplied with water from stocked streams, attention has been paid also to other fish species. The latter originated directly from the same investigated farm; stream over the farm, or localities from where the parent fish were obtained. 
The fish were examined in a native form and in some cases, in order to obtain a complete determination of protozoa and their stage of development, a certain number of samples was fixed in $4 \%$ formaldehyde for later processing by histological methods.

Altogether 979 specimens of the investigated fish species were examined post mortem for the presence of parasites. Of these, 164 were Barbus barbus (119 juvenile and 45 adult), 314 Chondrostoma nasus (270 juvenile and 44 adult), 374 Leuciscus cephalus (329 juvenile and 44 adult), and 128 Aspius aspius (juvenile only). Further 257 fish of other species underwent the same examination.

Methodical procedures were chosen to obtain the most complete data on the spectrum of the agents of invasive diseases, their pathological effect and possibly of other ill-health and were based on procedures recommended by Ergens and Lom (1970) and Lucký (1982).

The found parasites were immediately determined and isolated, fixed and preserved in a suitable way for a later precise determination. The methods used were based on procedures described in literature (Ergens and Lom 1970; Lucký 1982; Musselius et al. 1983; Schäperclaus et al. 1979). The actual determination was carried out according to various keys of determination (Bychovskij et al. 1962; Ergens and Lom 1970; Gusev et al. 1985; Lucký 1982; Shulman et al. 1984). The prevalence of the parasitic invasions was expressed in per cents of invaded fish in individual samples, their intensity by the number of protozoa found in a microscopical field at a certain magnification or by an absolute number (see Tables).

\section{Results}

a. Altogether 17 species of invasive disease agents were found in adult fish of the Barbus barbus species. Out of them, 7 belonged to protozoan species (Cryptobia branchialis, Myxobolus branchialis, Myxobolus cyprini, Chilodonella piscicola, Ichthyophthirius multifiliis, Trichodina fultoni, Tripartiella copiosa), 3 were monogenea species (Dactylogyrus carpathicus, D. malleus, Gyrodactylus katharineri), 1 tapeworm species (Bathybothrium rectangulum), 2 were identified as trematode species (Sanguinicola sp. - eggs, Diplostomum spathaceum - metacercariae), 1 species was a roundworm (Rhabdochona hellichi) 2 species were thorny-headed parasites (Acanthocephalus anguillae, Pomporhynchus laevis) and 1 leech (Piscicola geometra). The invasion of Myxobolus branchialis on gill, Bathybothrium rectangulum in intestine, Sanguinicola sp. eggs on gill and in internal organs, and Acanthocephalus anguillae in intestine can be regarded as more serious from the health status point of view (Plate XIII., Fig. 1).

b. In juvenile Barbus barbus fish (Table 1) 9 species of parasites were isolated, out of them, 8 protozoa (Ichthyobodo necator, Ichthyophthirius multifiliis, Apiosoma piscicola, Epistylis lwoffi, Trichodina acuta, T. nigra, Trichodinella epizootica, Tripartiella copiosa) and 1 monogenea (Dactylogyrus vastator). Health of the fish was not, however, affected by the invasion.

Table 1

Parasites of juvenile Barbus barbus

\begin{tabular}{|c|c|c|c|}
\hline Parasite & Localisation & Prevalence (\%) & Intensity \\
\hline $\begin{array}{l}\text { Ichthyobodo necator } \\
\text { Ichthyophthirius multifiliis } \\
\text { Ichthyophthirius multifiliis } \\
\text { Apiosoma piscicola } \\
\text { Epistylis lwoffi } \\
\text { Trichodina acuta } \\
\text { Trichodina acuta }+ \text { T. nigra } \\
\text { Trichodina acuta } \\
\text { Trichodinella epizootica } \\
\text { Tripartiella copiosa } \\
\text { Dactylogyrus vastator }\end{array}$ & $\begin{array}{l}\text { skin } \\
\text { skin } \\
\text { gills } \\
\text { skin } \\
\text { skin } \\
\text { skin } \\
\text { skin } \\
\text { gills } \\
\text { skin } \\
\text { gills } \\
\text { gills }\end{array}$ & $\begin{array}{l}0-20 \\
0-5,8 \\
0-10 \\
0-20 \\
0-10 \\
0-75 \\
0-70 \\
0-20 \\
0-14.3 \\
0-25 \\
0-5\end{array}$ & $\begin{array}{l}0-1 / 32 \times \\
0-1 / 32 \times \\
0-2 / 32 \times \\
0-4 / 32 \times \\
0-1 / 32 \times \\
0-30 / 32 \times \\
0-20 / 32 \times \\
0-2 / 32 \times \\
0-1 / 32 \times \\
0-100 / 32 \times \\
1\end{array}$ \\
\hline
\end{tabular}


c. In adult fish of the Chondrostoma nasus, 13 species of parasites were isolated out of them 8 protozoa (Myxobolus mïlleri, M. lobatus, Chilodonella piscicola, Ichthyophthirius multifiliis, Ambiphrya sp., Epistylis lwoffi, Trichodina pediculis,' Tripartiella copiosa), 2 species of monogenea (Dactylogyrus ergensi, Gyrodactylus macrocornis), 1 species of trematode metacercariae (Diplostomum spathaceum), 1 mite (Hydrozoetes lacustris) and 1 species of molluscs parasitizing in a larval stage (Anodonta sp.). The found invasions did not affect the health status of the adult nase.

d. In the juvenile Chondrostoma nasus (Table 2) 7 species of parasites were isolated, all of them belonging to protozoa (Ichthyobodo necator, Chilodonella piscicola, Ichthyophthirius multifiliis, Ambiphrya sp., Epistylis lwoffi, Trichodina pediculus, Tripartiella copiosa). Parasitic invasion was observed already in three-week old fish and the incidence in skin and gills of some of the parasites was high (Ambiphrya sp., Trichodina pediculus). However, greater losses in fry due to parasitic invasion were not found (Plate XIII., Fig. 2).

Table 2

Parasites of juvenile Chondrostoma nasus

\begin{tabular}{|c|c|c|c|}
\hline Parasite & Localisation & Prevalence (\%) & Intensity \\
\hline $\begin{array}{l}\text { Ichthyobodo necator } \\
\text { Chilodonella piscicola } \\
\text { Chilodonella piscicola } \\
\text { Ichthyophthirius multifiliis } \\
\text { Ichthyophthirius multifiliis } \\
\text { Ambiphrya sp. } \\
\text { Epistylis lwoff } \\
\text { Trichodina pediculus } \\
\text { Trichodina pediculus + Tripartiella copiosa } \\
\text { Trichodina pediculus } \\
\text { Tripartiella copiosa } \\
\text { Tripartiella copiosa }\end{array}$ & $\begin{array}{l}\text { skin } \\
\text { skin } \\
\text { gills } \\
\text { skin } \\
\text { gills } \\
\text { skin } \\
\text { skin } \\
\text { skin } \\
\text { skin } \\
\text { gills } \\
\text { skin } \\
\text { gills }\end{array}$ & $\begin{array}{l}0-30 \\
0-20 \\
0-3.3 \\
0-3.3 \\
0-10 \\
0-100 \\
0-45 \\
0-50 \\
0-73.3 \\
0-6.6 \\
0-50 \\
0-10\end{array}$ & $\begin{array}{l}0-5 / 32 \times \\
-10 \\
0-1 / 100 \times \\
0-1 / 100 \times \\
0-1 / 100 \times \\
0-100 / 32 \times \\
0-4 / 100 \times \\
0-50 / 32 \times \\
0-40 / 32 \times \\
10-60 / 32 \times \\
0-1 / 32 \times \\
0-1 / 32 \times\end{array}$ \\
\hline
\end{tabular}

e. In adults of the Leuciscus cephalus fish, out of 21 parasite species were isolated, of them 11 protozoa (Trypanosoma sp., Myxobolus mülleri, M. bramae, Chilodonella piscicola, Ichthyophthirius multifiliis, Apiososma piscicola, Trichodina pediculus, T. fultoni, T. nigra, Paratrichodina incissa, Tripartiella copiosa), 4 monogenea species (Dactylogyrus folkmanovae, D. sphyrna, D. vistulae, Gyrodactylus gasterostei), 2 tapeworm species (Caryophyllaeides fennica, Proteocephalus torulosus), 1 trematode metacercariae species (Diplostomum spathaceum), 1 roundworm species (Rhabdochona denudata), 1 thorny-headed parasite species (Acanthocephalus anguillae), 1 leech (Piscicola geometra). The invasion of Myxobolus mülleri on gills and of Proteocephalus torulosus in intestine can be regarded in some cases as more serious.

f. In juvenile Leuciscus cephalus fish (Table 3 ) 8 species of parasites were isolated, all of them being protozoa (Ichthyobodo necator, Myxobolus pseudodispar, Chilodonella piscicola, Ichthyophthirius multifiliis, Epistylis lwoffi, Apiosoma piscicola, Trichodina pediculus, Tripartiella copiosa). Greater losses were not, however, found. It should also be pointed out that skin chilodonellosis, being observed in its early stages in two-week old fish, was not found in adult fish. This can be ascribed to the effect of control measures. 
Table 3

Parasites of juvenile Leuciscus cephalus

\begin{tabular}{llll}
\hline Parasite & Localisation & Prevalence (\%) & Intensity \\
\hline Ichthyobodo necator & skin & $0-25$ & $0-15 / 32 \times$ \\
Myxobolus pseudodispar & gills & $0-5$ & 1 cyst \\
Myxobolus pseudodispar & musculature & $0-20$ & $1-2$ cysts \\
Chilodonella piscicola & skin & $0-40$ & $1-60$ \\
Ichthyophthirius multifiliis & skin & $0-5$ & $0-1 / 32 \times$ \\
Ichthyophthirius multifiliis & gills & $0-10$ & $1-6$ \\
Apiosoma piscicola & skin & $0-20$ & $0-1 / 100 \times$ \\
Apiosoma piscicola & gills & $0-10.5$ & $0-1 / 32 \times$ \\
Epistylis lwoffi & skin & $0-70$ & $0-8 / 32 \times$ \\
Epistylis lwoffi & gills & $0-30$ & $0-3 / 32 \times$ \\
Trichodina pediculus & skin & $0-73.3$ & $0-12 / 32 \times$ \\
Trichodina pediculus & gills & $0-5$ & $0-1 / 32 \times$ \\
Tripartiella copiosa & skin & $0-35$ & $0-3 / 32 \times$ \\
Tripartiella copiosa & gills & $0-65$ & $0-100 / 32 \times$ \\
\hline
\end{tabular}

g. Seven parasite species were isolated in juvenile Aspius aspius (Table 4), out of them 5 protozoan species (Ichthyobodo necator, Ichthyophthirius multifiliis, Apiosoma piscicola, Epistylis lwoffi, Trichodina nigra), 1 trematode metacercariae (Cotylurus pileatus) and 1 roundworm species in a larval stage. Parasitic invasions were observed already in two-week old fish. Losses caused by invasive diseases were not found, although the incidence of several of them (Apiosoma piscicola and Trichodina nigra in skin, Cotylurus pileatus in body cavity) was high and reached as much as $80-96.6 \%$. Attention should be paid to the fact that the extensive invasion of Trichodina nigra in two-week old fish was not observed in five- and six-week old ones which can again be explained by the efficacy of control measures. The ease with which the parasitic fauna can be imported and enriched with other species, if the veterinary inspection is not carried out, can be shown on the case of imported Aspius aspius from Hungary.

Table 4

Parasites of juvenile Aspius aspius

\begin{tabular}{llll}
\hline Parasite & Localisation & Prevalence (\%) & Intensity \\
\hline Ichthyobodo necator & skin & $0-3.3$ & $0-1 / 100 \times$ \\
Ichthyobodo necator & gills & $0-5$ & $0-1 / 100 \times$ \\
Ichthyophthirius multifiliis & skin & $0-5.5$ & 1 \\
Ichthyophthirius multifiliis & gills & $0-40$ & $1-3$ \\
Apiosoma piscicola & skin & $0-96.6$ & $0-10 / 100 \times$ \\
Apiosoma piscicola & gills & $0-60$ & $0-15 / 100 \times$ \\
Epistylis lwoffi & skin & $0-25$ & $0-3 / 32 \times$ \\
Trichodina nigra & skin & $0-94.4$ & $0-10 / 32 \times$ \\
Trichodina nigra & gills & $0-5.5$ & $0-1 / 100 \times$ \\
Cotylurus pileatus & body cavity & $0-80$ & $1-9$ \\
Nematoda gen. sp. larv. & body cavity & $0-10$ & 1 \\
& & & \\
\hline
\end{tabular}

h. In adult fish of other species (Rutilus rutilus, Scardinius erythrophthalmus, Tinca tinca, Carassius carassius) originating from the MO ČSR Třebíč-Poušov Hatchery or from localities from which the examined adult fish were obtained, six parasite species were found that can be characterized as common (Zschokkella nova, Ichthyophthirius multifiliis, Trichodinella epizootica, Ligula intestinalis plerocercoid, Diplostomum spathaceum - metacercariae, Tylodelphys clavata - 
metacercariae). Thus, in the reared fry of the investigated fish two parasite species were observed (Ichthyophthirius multifilliis, Trichodinella epizootica), these being found also in adult fish of other species in the above mentioned localities. The health status of the adult fish of other species was found to be good.

i. In juvenile fish of other species reared at the MO ČSR Třebič́-Poušov Hatchery (Salmo trutta, S. gairdnerii, Coregonus lavaretus, Thymallus thymallus, Esox lucius, Cyprinus carpio, Hypophthalmichthys molitrix, Silurus glanis, Ictalurus punctatus, Lota lota, Stizostedion lucioperca) altogether 14 parasites were isolated, out of them 9 protozoa (Ichthyobodo necator, Chilodonella piscicola, Ichthyophthirius multifiliis, Ambiphrya sp., Apiosoma piscicola, Epistylis lwoffi, Trichodina nigra, T. pediculus, T. acuta) 3 monogenea species (Dactylogyrus vastator, Gyrodactylus luciopercae, Paradiplozoon sp. - diporpa), 1 tapeworm species (Proteocephalus sp. - juvenile), 1 trematode metacercariae (Diplostomum spathaceum). All these protozoa were also found in the fry of the investigated fish. This confirms a general spread of these parasites in the investigated fish-breeding farm.

\section{Discussion}

The findings of parasites in adult barbels correspond in most cases to the literature data on the parasite spectrum in Barbus barbus and of their spread, our country and their localisation in hosts. Cysts of the Myxobolus branchialis sporozoon were found very frequently in gills of adult barbels coming from various areas on the Jihlava river although Ergens and Lom (1970) regard M. branchialis to be a relatively rare parasite of Barbus barbus in the Danube basin. Taking into account the literature data (Shulman et al. 1934), the finding of Myxobolus cyprini cysts in bulbus arteriosus and in kidneys of barbels coming from the Ivancice area on the Jihlava river is unusual. The authors report that a whole series of carp fish (31) can serve as hosts to $M$. cyprini but the barbel is not included. This finding thus expands the so far known spectrum of hosts of this parasite. The broadening of the host spectrum concerns also the isolation of Trichodina fultoni on skin and gills and of Tripartiella copiosa on gills. The isolation of small formations reminding of eggs of the blood fluke (Sanguinicola sp.) in internal organs (mostly in liver and kidneys) and on the gills of adult barbels appears to be very frequent. With regard to the scarce literature data on this parasite in Barbus barbus it is very interesting. These formations obstructed blood vessels and caused circulation disorders (Fig. 1).

As it was already presented in the Results section mostly protozoan parasites with not well pronounced host specificity were found in juvenile barbels. The same applies also to Epistylis, Trichodina acuta, Trichodina nigra and Tripartiella copiosa. The barbel is not, however, reported in literature as being a host of these parasites (Ergens and Lom 1970; et al. 1989; Shulman et al. 1984). Due to the occurrence in our area and a relatively broad spectrum of the mentioned hosts the observed invasions cannot be regarded as unusual but we have to consider them as broadening the host spectrum. The isolation of adult monogenea of Dactylogyrus vastator in an uncommon host, in Barbus barbus, appears to be very interesting. Gusev et al. (1985) refer to Carassius carassium, C. auratus gibelio, Cyprinus carpio and C. carpio haematophterus as being hosts of this parasite. The 
presence in other hosts was observed by e.g. Kašták (1956) in Vimba vimba. Also Gusev et al. (1985) report on similar cases. The level of the observed invasion was, however, so low that it had not affected the health condition of the reared stock. Dactylogyrus vastator could have got into the rearing ditch ponds through tributary water or fishing gear. At the time of the isolation, carp stock that could possibly be infected with the parasite was reared on the premises. The possibility of mistaking this parasite for Dactylogyrus crassus was excluded by morphological examination of isolated specimens and comparison with literature data presented by Gusev et al. (1985).

Similarly as in the case of adult barbels, the spectrum of parasites found in adult nase corresponded to that presented in most literature information on the parasite spectrum and their spread in our area and their localisation in a host. The only exception was the isolation of Ambiphrya sp. on the skin, nostrils and on the gills of parent nases. Since the observed morphological finding did not correspond with any described species of Ambiphrya (Shulman et al. 1984) the parasites were simply denoted as Ambiphrya sp. (Fig. 2). The nase is not presented in literature as being a host of Epistylis lwoffi, Trichodina pediculus, Tripartiella copiosa. With regard to the occurrence of these parasites in our area and to a relatively broad spectrum of their hosts their isolation in Chondrostoma nasus cannot be considered unusual but as broadening the host spectrum.

The observed parasitic fauna of juvenile nases was represented by ectoparasitic protozoa with only slightly pronounced specificity. Ambiphrya sp., Epistylis lwoffi, Trichodina pediculus and Tripartiella copiosa were among species isolated in Chondrostoma nasus and their occurrence was discussed previously.

Similarly as in adult fish of the preceding species, the finding of parasites in adult chubs corresponded in most cases to literature data on the spectrum of parasites and their spread in our area, and their localisation in the host. The final determination of flagellates of Trypanosoma sp. could not be carried out due to the poor quality of the stained preparation. Although the Leuciscus cephalus $\mathrm{sp}$. have not been presented in literature as a host of Trichodina fultoni the finding cannot be considered as unusual. The broad host spectrum, as presented e.g. by Shulman et al. (1984) confirms the only slightly pronounced host specificity.

The parasitic fauna of the examined juvenile chubs consisted mostly of ectoparasitic protozoa. Although in case of Epistylis liwoffi the Leuciscus cephalus is not reported as being a host Shulman et al. (1984) admit a relatively broad spectrum of hosts and our findings correspond with this opinion.

The parasitic fauna of juvenile asps also consisted mostly of ectoparasitic protozoa and their occurrence and localisation in hosts were not contradictory with the literature data. In literature presented host spectrum of these parasites is so broad that their occurrence in Aspius aspius cannot be considered as surprising. The isolation of metacercariae Cotylurus pileatus in the body cavity of imported Aspius aspius from Hungary cannot be regarded as unusual. The pathogenicity of the observed invasion is difficult to assess. The fact is that the death of fish not observed and the nutriture was also found to be good. A relatively high prevalence of the invasion confirms that the imported fish came from areas with a higher concentration of gulls - definite hosts - and at the same time from areas where first intermediate hosts occur. The only finding of the roundworm larva in the body cavity of juvenile asp cannot be considered as too important from the fish health point of view. 
All parasites found in other adult fish belonged to the group of commonly occurring parasites with only slightly pronounced host specificity as reported in various literature data (e.g. Bychovskij et al. 1962; Ergens and Lom 1970; Shulman et al. 1984; Vojtek 1974). Two species of protozoa (Ichthyophthirius multifiliis and Trichodinella epizootica) were isolated also in the fry of the fish studied in more detail. The parasites found did not affect the health of fish.

Most of the parasites isolated in the fry of other fish reared in the fish-breeding farm at Třebič́-Poušov were found also in the fry of the investigated fish species. It confirms a common spread of these parasites in the surveyed fish-rearing farm.

The fry of the investigated fish species obtained by stripping is endangered particularly by ectoparasitic protozoa with not well pronounced host specificity already in the first weeks of life. Good level of feeding and zoohygienic conditions together with the preventive antiparasitic baths in malachite green were adequate to maintain good health status of the fry of the investigated fish, without greater losses in stock and without the risk of spreading the invasive diseases.

In many fish-breeding farms the incorporation of aethiological agents, e.g. with tributary water or fishing gear (it applies fully to the investigated fish-breeding farm) cannot be excluded. Thus, it is necessary to provide good conditions of breeding (ample natural food, convenient temperature of water and its chemism), regular examination of health of the fish and subsequent efficient preventive antiparasitic baths. Also, it is necessary to prevent the uncontrolled import of the fry and stock fish from abroad. The presented measures, based directly on the results of investigation, should be complemented by an efficient sanitation of rearing premises after the hatching and rearing were finished, by a permanent examination of the health status of fish in the hatchery and rearing farm with their controlled stocking, or by declaring a veterinary protection area and introducing "all in all out" system for parent fish.

\section{Parazitózy plůdku vybraných druhư řičních ryb v podmínkách umělého výtěru a odchovu}

V letech 1984 až 1989 byla na specializovaném rybochovném zařizení Českého rybářského svazu v Třebíči-Poušově, které leží na řece Jihlavě (povodí Dunaje), sledována problematika parazitárních invazí uměle rozmnožovaného a odchovávaného plůdku řičních druhů ryb (Barbus barbus, Chondrostoma nasus, Leuciscus cephalus, Aspius aspius). Parazitologicky bylo vyšetřeno 979 kusů sledovaných druhů ryb (846 juvenilních, 133 adultních) a 257 kusů jiných druhů ryb.

Odchovávaný plůdek sledovaných druhů ryb byl již v prvních týdnech života ohrožován především ektoparazitickými prvoky s nepřiliš vyhraněnou hostitelskou specifičností.

Při odchovu je třeba zajistit dobré chovatelské podmínky, pravidelné sledování zdravotního stavu a na jeho základě provádění účinných preventivních antiparazitárnich koupeli. Tato opatření je vhodné doplnit účinným způsobem asanace odchovných zařizení, sledováním zdravotního stavu ryb $\mathrm{v}$ napáječi líhně a odchovny a jeho kontrolovaným nasazováním, popřípadě vyhlášením veterinárního ochranného pásma a zavedením uzavřeného obratu hejna generačních ryb. 


\section{Паразитозы мапьков избранных видов речной рыбы в үсловиях искусственной откладки икры и разведения}

В 1984 - 1989 гг. проводили на специализированном рыбоводческом объекте Чешского рыбоводческого союза в Тршебиче-Поушов, распопоженного на реке Йиглаве (бассейн Дүная), исследования проблемагики паразытарной инвазии искусственно размножаемых и разводимых мальков речных видов рыбы (Barbus barbus, Chondrostoma nasus, Leuciscus cephalus, Aspius aspius). Паразитологически исследовали 979 штүк изучаемых видов рыбы (846 ювенильных, 133 взрослых) и 257 штук других видов рыбы.

Разводимые мальки исследуемых видов рыбы үже в течение первых недель жизни находились под угрозой прежде всего эктопаразитическими простейшими с не особо четко определенной спецификой хозяина.

В процессе разведения необходимо обеспечить его хорошие условия, регулярное исследование состояния здоровья и, исходя из резульгатов, проведение эффективных профилактических антипаразитарных ванн. Данные меры целесообразно дополнить эффективным оздоровлением рыбоводческого оборудования, исследованием состояния здоровья рыбы в инкубационной и рыборазводне, контролируемой рыбопосадкой, а также объявлением ветеринарной защитной зоны и внедрением закрытого оборота косяка маточной рыбы.

\section{References}

BAUER, O. N.-MUSSELIUS, V. A.-STRELKOV, J. A.: Bolezni prudovych ryb. Moskva, Legkaja i piščevaja promyšlennost', 1981: 320 p.

BYCHOVSKIJ, B. E. et al.: Opredělitěl parazitov presnovodnych ryb SSSR. Moskva-Leningrad, Izdatělstvo Akaděmii nauk SSSR, 1962: $776 \mathrm{p}$.

DYK, V.: Nemoci ryb. Praha, CAZ, 1961: 404 p.

ERGENS, R.-LOM, J.: Pủvodci parazitárních nemocí ryb. Praha, Academia, 1970: 383 p.

GUSEV, A. V. et al.: Opredělitěl parazitov presnovodnych ryb fauny SSSR. Red. Bauer, O. N., T. 2. Parazitičeskije mnogokletočnyje. Leningrad, Nauka, 1985: $425 \mathrm{p}$.

JIRÁSEK, J.: Chov kapra. In: SPAČEK, F. et al.: Speciální chov hospodářských zvířat 2. Praha-Bratislava, SZN - Príroda, 1980: 475-492

KAŠTÁK, V.: Predbežná zpráva o nálezoch cudzopasníkov rýb $\mathrm{v}$ slovenských vodách. Biológia, 11, 1956: 624-635

KOURIL, J. - SVOBODOVÁ, Z.-VYKUSOVÁ, B.-HAMÁCKKOVÁ, J.: Antiparazitární a protiplísňové koupele raného plưdku kapra, býložravých ryb a sumce. Metodika VÚRH Vodňany, 1984: $8 \mathrm{p}$.

KRUPKA, I.: Umělý výtěr a odchov plůdku parmy. Metodika VÚRH Vodňany, 1987: 13 p.

LOM, J.-DYKOVA, I. et al.: Protozoární paraziti užitkových ryb. Praha, ČRS-SZN, 1989: $103 \mathrm{p}$.

LUCKÝ, Z.: Metodické návody $\mathrm{k}$ diagnostice nemocí ryb. Praha, SPN, 1982: $150 \mathrm{p}$.

LUCKYY, Z.: Choroby chovných ryb. Praha, SPN, 1986: 201 p.

LUCKÝ, Z.: Péče o zdraví a prevence chorob ryb. Praha, Naše vojsko, 1986: $188 \mathrm{p}$.

LUCKYY, Z. - NAVRÁTIL, S.: Veterinární zásady při řízené reprodukci ryb. In: Reprodukce a genetika ryb. Sborník referátů z vědecké konference. Vodňany, Slovenská zoologická společnost, 1986: 204-210

MARKEVITCH, A. P.: Parazitofauna presnovodnych ryb SSSR. Kijev, Izdatělstvo Akaděmii nauk USSR, 1951: $376 \mathrm{p}$.

MOLNÁR, K.: Ưber die Parasitenfauna der Fische in Ungarn. II. Bekannte und neue Dactylogyrus - Arten an einheimischen Fischen. Acta Vet. Hung., 14, 1964: 455-467

MOLNÁR, K.: Beiträge zur Kenntnis der Fischenparasiten in Ungarn. 3. Weitere Monogeneidenarten aus Fischen. Acta Vet. Hung., 18, 1968: 295-311 
MOLNÁR, K.: Beiträge zur Kenntnis der Fischenparasitenfauna Ungarns IV. Trematoden. Parasit. Hung., 2, 1969: 119-136

MOLNÁR, K.: Beiträge zur Kenntnis der Fischenparasitenfauna Ungarns VI. Cestoda, Nematoda, Acanthocephala, Hirudinea. Parasit. Hung., 3, 1970: 51-76

MORAVEC, F.: Nematodes of fishes in Czechoslovakia. Přírodovědné práce ústavů ČSAV v Brně, 5, 1971: 1-49

MUSSELIUS, V. A. et al.: Laboratornyi praktikum po boleznjam ryb. Moskva, Legkaja i piščevaja promyšlennost', 1983: $296 \mathrm{p}$.

PECHA, O.: Umělý výtěr bolena. In: Reprodukce a genetika ryb. Sborník referátů z vědecké konference. Vodňany, Slovenská zoologická společnost, 1986: 160-166

PELLÉRDY, L. - MOLNÁR, K.: Known and unknown eimerian parasites of fishes in Hungary. Folia parasitol. (Praha), 15, 1968: 97-105

PLEHN, M.: Praktikum der Fischkrankheiten. In: Handbuch der Binnenfischerei Mitteleuropas I. Stuttgart, E. Schweizertbartsche Verlagsbuchhandlung, 1924: $301-470$

SCHÄPERCLAUS, W. et al.: Fischkrankheiten. Berlin, Akademie Verlag, 1979: 1089 p.

SHULMAN, S. S. et al.: Opredělitěl parazitov presnovodnych ryb fauny SSSR. Red. Bauer, O. N., T. 1. Parazitičeskije prostějšije. Leningrad, Nauka, 1984: 432 p.

VOJTEK, J.: Metacerkarie z ryb Ceskoslovenska. Folia Fac. Sci. Nat. Univ. Purkynianae Brunensis. Biologia, 44, (2), 1974: 13-51

VOJTEK, J. - FOLKMANOVA, B. - ERGENS, R.: Příspěvek k poznání cizopasníků ryb jižní Moravy. Práce Brněnské základny ĆSAV, 26, 1954: 1-24

ŽITNAN, R.: Poznatky z helmintologického výskumu rýb východného Slovenska. Zborník Východoslovenského múzea v Košiciach A, 1, 1960: 135-147 




Fig. 1. (A) Liver tissue with a vessel containing a Sanguinicola sp. egg. Host: Barbus barbus. HE. $\times 1000$.

Fig. 2. ( $\nabla)$ Ambiphrya sp. Host: Chondrostoma nasus. Giemsa. x 1000.

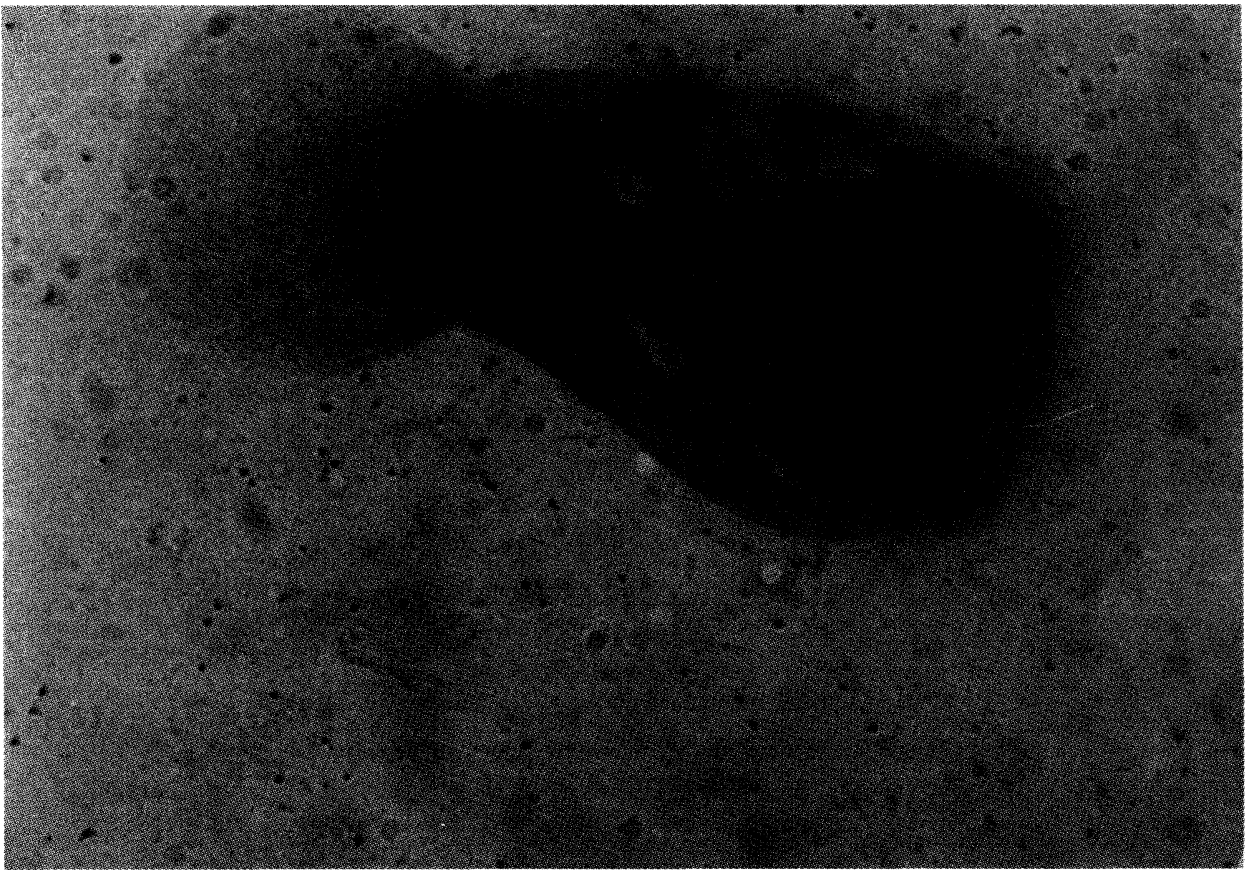

